\title{
Laser-Aided Ceramic Bracket Debonding: A Comprehensive Review
}

\author{
Rezvaneh Ghazanfari', Hanieh Nokhbatolfoghahaei ${ }^{2}$, Marzieh Alikhasi ${ }^{3 *}$ \\ ${ }^{1}$ Department of Dental Prosthesis and Implants, School of Dentistry, Tehran University of Medical Sciences, Tehran, \\ Iran \\ ${ }^{2}$ Laser Research Center of Dentistry, Dentistry Research Institute, School of Dentistry, Tehran University of Medical \\ Sciences, Tehran, Iran \\ ${ }^{3}$ Dental Research Center, Laser Research Center of Dentistry, Dental Implant Research center, School of Dentistry, \\ Tehran University of Medical Sciences, Tehran, Iran
}

\author{
*Correspondence to \\ Marzieh Alikhasi, DDS; Dental \\ Research Center, Laser Research \\ Center of Dentistry, Dental Implant \\ Research center, School of Dentistry, \\ Tehran University of Medical \\ Sciences, Tehran, Iran. \\ Tell: +98-188196809; Fax:+98- \\ 2188196832; \\ Email: m_alikhasi@yahoo.com
}

Published online 7 January 2016

\begin{abstract}
Different techniques have been introduced for the removal of ceramic brackets. Since the early 1990s, lasers have been used experimentally for debonding ceramic brackets. The goal of this study is to give a comprehensive literature review on laser-aided ceramic bracket debonding. PubMed and Google Scholar databases were used to identify dental articles with the following combination of key words: Ceramic brackets, Debonding, and Laser. Sixteen English articles from 2004 to 2015 were selected. The selected studies were categorized according to the variables investigated including the intrapulpal temperature, shear bond strength, debonding time, enamel damage and bracket failure. Most articles reported decreased shear bond strength and debonding time following laser irradiation without any critical and irritating increase in pulpal temperature. There were no reports of bracket failure or enamel damage. Laser irradiation is an efficient way to reduce shear bond strength of ceramic bracket and debonding time. This technique is a safe way for removing ceramic bracket with minimal impact on intrapulpal temperature and enamel surface and it reduces ceramic bracket failure.
\end{abstract}

Keywords: Laser; Ceramic; Bracket; Debonding.

\section{Introduction}

Ceramic brackets were introduced in the mid-1980s and were aesthetically acceptable for adult patients. ${ }^{1}$ Ceramic brackets are composed of polycrystalline alumina, single-crystal alumina, or zirconia. ${ }^{2}$ Compared to metallic brackets, ceramic brackets have lower fracture toughness and higher bond strength. ${ }^{3}$ Being brittle, ceramic bracket cannot be peeled away from the enamel tooth surface like ductile metal brackets. ${ }^{4}$ Pliers, which apply shear forces, and wrenches (torsional forces) could be used to remove ceramic brackets. However, these techniques could cause enamel fracture and bracket failure or breakage. ${ }^{5}$

To facilitate ceramic bracket removal, the bond strength can be reduced. Reduced bond strength can be achieved by chemically changing the bond between bracket and adhesive ${ }^{6}$ or by using wood-burning pens, warm air dryers, specifically designed electrothermal debonding devices (ETD) or lasers that thermally soften the adhesive. ${ }^{7}$ The limitation of these techniques is the increase in intrapulpal temperature which should never exceed $5.5^{\circ} \mathrm{C}$ as defined by Zach and Cohen. ${ }^{7}$ Other methods of ceramic bracket removal such as the electrothermal device deliver up to $30 \mathrm{~J}$ of energy and soften the composite adhesive above a critical temperature (approximately $150^{\circ} \mathrm{C}$ to $200^{\circ} \mathrm{C}$ ).

With the laser-based technique, debonding occurs within 1 to 5 seconds and does not cause patient discomfort or irreversible pulpal changes. Electrothermal has two additional disadvantages ${ }^{1}$ : the whole assembly head must cool down after the removal of a few brackets, ${ }^{2}$ and the instrument is designed to fit only one specific bracket design. ${ }^{5}$ One study showed that the electrothermal technique could remove a ceramic bracket in less than 4 seconds without significant pulpal damage. Another investigation found that more than 1 minute is needed for removal and the increase in bonding interface temperature is more than $160^{\circ} \mathrm{C}$ for all nine bonding agents. ${ }^{4}$

Ultrasonic debonding could also be used to remove ceramic brackets. ${ }^{3}$ With this approach, enamel damage and bracket failure could be decreased, and the same ultrasonic tip also removes remnant adhesive. This technique has two drawbacks-it is time consuming and requires a moderate magnitude of force. ${ }^{3}$

Since the early 1990s, lasers have been used experimen-

Please cite this article as follows: Ghazanfari R, Nokhbatolfoghahaei H, Alikhasi M. Laser-aided ceramic bracket debonding: a comprehensive review. / Lasers Med Sci. 2016;7(1):2-11. doi:10.15171/jlms.2016.02. 
tally for debonding ceramic brackets. ${ }^{4,5,8}$ Many different studies have been done to investigate the applicability of various lasers for ceramic bracket removal including carbon dioxide $\left(\mathrm{CO}_{2}\right)$ laser, diode, Erbium-Doped Yttrium Aluminum Garnet

(Er:YAG), Neodymium-Doped Yttrium Aluminium Garnet (Nd:YAG), etc. The aim of this study is to give a comprehensive literature review on laser-aided ceramic bracket debonding.

\section{Methods}

PubMed and Google Scholar databases were explored for dental articles with the following combination of key words: Ceramic brackets, Debonding and Laser. Sixteen articles from 2004 to 2015 were identified. Articles selected for this review were in English language, available in full text format and designed to evaluate the applicability and safety of laser aided ceramic bracket debonding. To understand the efficiency of laser aided debracketing, we focused on answering these questions:

(1) "Is the laser approach effective in reducing shear bond strength and debonding time of ceramic brackets?" This was answered by 13 articles.

(2) "Is the laser approach effective in reducing debonding time?" This was answered by 2 articles.

(3) "Can the laser approach be used for debracketing with less bracket failure?" This was answered by 3 articles.

(4) "Can the laser approach be used for debracketing with minimal enamel damage?” This was answered by 11 articles.

(5) "How much does the laser approach increase intrapulpal temperature?" This was answered by 9 articles.

\section{Results}

Studies selected were categorized according to variables including intrapulpal temperature, shear bond strength, debonding time, enamel damage and bracket damage. Importantly, the debonding process could also be affected by many variables such as bracket type, resin composition, laser type, lasing mode, lasing time, laser power and time lag between lasing and debonding.

\section{Effects of Laser Irradiation on Shear Bond Strength}

In many articles the efficiency of laser irradiation during ceramic bracket removal was investigated based on the effect of laser irradiation on shear bond strength. For example, Iijima et al, ${ }^{2}$ Marci et al, ${ }^{9}$ Tehranchi et al ${ }^{10}$ and Saito et $\mathrm{al}^{11}$ used $\mathrm{CO}_{2}$ laser for debracketing. Iijima et $\mathrm{al}^{2}$ and Tehranchi et $\mathrm{al}^{10}$ found diminished shear bond strength. In both studies, a lasing time of 5 seconds was used and laser irradiation was done at different powers of 3-6 W and $50 \mathrm{~W}$, respectively (Table 1 ).

Using experimentally produced 4 META/MMA-TBB resin orthodontic adhesives containing 30 and $40 \mathrm{wt} \%$ thermal expansion microcapsules and different lasing durations (4, 5 and 6 seconds), Saito et $\mathrm{al}^{11}$ found the bond strength of adhesive containing $40 \mathrm{wt} \%$ microcapsules was sufficient for orthodontic treatment and decreased significantly to $0.40-0.48$-fold (4.6 5.5 $\mathrm{MPa}$ ) by $\mathrm{CO}_{2}$ laser irradiation for 5 or 6 seconds versus the non-laser groups. Investigating the effect of a diode laser on shear bond strength of ceramic brackets, Feldon et $\mathrm{al}^{13}$ and Almohaimeed et $\mathrm{al}^{18}$ found that diode laser could significantly decrease shear bond strength of monocrystalline bracket and pre-coated ceramic brackets, respectively. Oztoprak et al, ${ }^{14}$ Nalbantgil et al, ${ }^{15}$ Nalbantgil et $\mathrm{al}^{19}$ and Tozlu et $\mathrm{al}^{16}$ investigated the effect of Er:YAG laser on debonding. Oztoprak et $\mathrm{a}^{14}$ found that the Er:YAG laser at $4.2 \mathrm{~W}$ for 9 seconds was effective in reducing shear bond strength of poly crystalline ceramic brackets. Nalbantgil et $\mathrm{al}^{15}$ also showed that different lasing durations (3, 6 and 9 seconds) were efficient in debonding polycrystalline brackets. In comparing the shear bond strength of ceramic bracket after different time lags between lasing and debonding, Tozlu et $\mathrm{al}^{16}$ concluded that the ideal parameter was 6 seconds of Er-YAG laser irradiation followed by 18 seconds of time lag for debonding. However, care should be taken not to exceed this limit. In Nalbantgil et $\mathrm{al},{ }^{19}$ laser irradiation was studied with or without water cooling. They showed that the Er-YAG laser-aided debonding-with or without water-cooling-was effective for debonding ceramic brackets by reducing resin shear bond strength.

Hayakawa $^{12}$ et al used Nd:YAG laser for debonding at 1.0, 2.0 or $3.0 \mathrm{~J}$. They concluded that the application of a high-peak power Nd:YAG laser at 2.0 or $3.0 \mathrm{~J}$ considerably lowered or eliminated the bond strength. They also found that at the 2.0-J level, the polycrystalline ceramic brackets demonstrated a significant decrease in bond strength versus the single-crystal ceramic brackets. No significant differences were reported among the different types of adhesive resins (4-META/MMA and Bis-GMA). Using the same laser at $3 \mathrm{~W}$ for debonding of polycrystalline brackets, Han et $\mathrm{al}^{3}$ found that the Nd:YAG laser could ease ceramic brackets removal.

Sarp et $\mathrm{al}^{8}$ used a 1070 nanometer ytterbium fiber laser in continuous wave $(\mathrm{CW})$ and modulated mode at 18 W. They observed significantly reduced bond strength, debonding time and work done while debonding the ceramic brackets (Table 2 ).

Laser Irradiation and Intrapulpal Temperature One of the major concerns when using a laser for ceramic bracket debonding is potential thermal irritation of pulp caused by laser irradiation. According to Zach and Cohen ${ }^{20} 1.8^{\circ} \mathrm{C}$ intrapulpal temperature increase causes no damage, but a $5.5^{\circ} \mathrm{C}$ temperature increase could cause pulp necrosis in $15 \%$ of teeth.

Ahrari et al, ${ }^{1}$ Saito et $\mathrm{al}^{11}$ and Marci et $\mathrm{al}^{9}$ studied the effect of $\mathbf{C O}_{2}$ laser irradiation on pulp chamber temperature and used different parameters (Table 3). They reported that the intrapulpal temperature was below the benchmark of $5.5^{\circ} \mathrm{C}$. Feldon et $\mathrm{al}^{13}$ and Ivanov et $\mathrm{al}^{21}$ debonded both kinds of monocrystalline and polycrystalline ceramic brackets with a diode laser. Feldon et $\mathrm{al}^{13}$ reported that the mean increases in pulp chamber temperature 
Table 1. Studies Investigating Shear Bond Strength During Laser Aided Ceramic Bracket Removal

\begin{tabular}{|c|c|c|c|c|}
\hline Author & Groups & Laser & Brackets Cement & Results/Conclusion \\
\hline $\begin{array}{l}\text { Hayakawa } \\
\text { et } \mathrm{al}^{12}\end{array}$ & $\begin{array}{l}\mathrm{n}=5 \\
\text { Group 1: Single crystal } \\
\text { subgroup 1, 2, 3, 4: MMA } \\
\text { (Control, } 1 \mathrm{~J}, 2 \mathrm{~J}, 3 \mathrm{~J} \text { ) } \\
\text { Subgroup 5, 6, 7,8: Bis-GMA } \\
\text { (Control, } 1 \mathrm{~J}, 2 \mathrm{~J}, 3 \mathrm{~J} \text { ) } \\
\text { Group 2: poly crystal } \\
\text { Subgroup 1, 2, 3, 4: MMA } \\
\text { (Control, } 1 \mathrm{~J}, 2 \mathrm{~J}, 3 \mathrm{~J} \text { ) } \\
\text { Subgroup 5, 6, 7, 8: Bis-GMA } \\
\text { (Control, } 1 \mathrm{~J}, 2 \mathrm{~J}, 3 \mathrm{~J} \text { ) }\end{array}$ & $\begin{array}{l}\text { Nd:YAG } \\
W L=1060 \mathrm{~nm} \\
\text { Pulse duration=1.2 } \\
\text { ms } \\
5 \text { pulses per second } \\
* 2 \text { points on each } \\
\text { bracket } \\
* 1 \text { pulse per second } \\
\text { shot } \\
P=1.0,2.0,3.0 \mathrm{~J} .\end{array}$ & $\begin{array}{l}\text { *single crystal (Inspire) \& } \\
\text { polycrystalline (Clarity) } \\
\text { *4-META/MMA \& Bis- } \\
\text { GMA) }\end{array}$ & $\begin{array}{l}\text { Every specimen in the } 2.0-\mathrm{J} \text { and } 3.0-\mathrm{J} \text { groups showed a } \\
\text { significant decrease in bonding strength compared with } \\
\text { the non-irradiated group. However, the } 1.0-\mathrm{J} \text { group did } \\
\text { not show such difference. In the } 2 \text { former groups, laser } \\
\text { irradiation alone was enough to debond some specimens. } \\
\text { No significant difference was observed between bonding } \\
\text { resins. } \\
\text { At the } 2.0-\mathrm{J} \text { level, polycrystalline ceramic brackets showed } \\
\text { a significant decrease in bond strength compared with } \\
\text { single-crystal ceramic brackets. } \\
\text { No significant differences were observed among different } \\
\text { types of adhesive resins. }\end{array}$ \\
\hline Han et $\mathrm{al}^{3}$ & $\begin{array}{l}\mathrm{N}=30,3 \text { groups } \\
\text { (1) metallic brackets + shear } \\
\text { debonding force } \\
\text { (2) ceramic brackets + shear } \\
\text { debonding force } \\
\text { (3) ceramic brackets + } \\
\text { Nd:YAG laser }\end{array}$ & $\begin{array}{l}\text { Nd:YAG } \\
W L=1060 \mathrm{~nm} \\
P=3 \mathrm{~W} . \\
T=3 \mathrm{~s} . \\
D=1 \mathrm{~mm} .\end{array}$ & $\begin{array}{l}\text { * Metallic (MBT)/ } \\
\text { polycrystalline ceramic } \\
\text { brackets (clarity) } \\
\text { *Cement: not mentioned }\end{array}$ & $\begin{array}{l}\text { Laser irradiation could significantly reduce shear bond } \\
\text { strength (SBS). }\end{array}$ \\
\hline lijima et $a^{2}$ & $\begin{array}{l}{ }^{*} \mathrm{~N}=50 \\
10 \text { groups (for shear bond } \\
\text { strength \& nanoindentation } \\
\text { test }\end{array}$ & $\begin{array}{l}\mathrm{CO}_{2} \\
\mathrm{WL}^{2}=10.6 \mathrm{~mm} \\
\mathrm{~T}=5 \mathrm{~s} . \\
\mathrm{P}=3,4,5,6 \mathrm{~W}\end{array}$ & $\begin{array}{l}\text { *Single-crystal brackets } \\
\text { *Conventional etch and } \\
\text { rinse adhesive system } \\
\text { self-etching adhesive } \\
\text { system transbond plus } \\
\text { (for measurements of } \\
\text { shear bond strength \& } \\
\text { nanoindentation test) }\end{array}$ & $\begin{array}{l}\text { The bracket shear bond strength diminished under all } \\
\text { laser irradiation. }\end{array}$ \\
\hline Feldon et $\mathrm{al}^{13}$ & $\begin{array}{l}\text { *Clarity/force only } \\
{ }^{*} \text { Inspire ICE/force only } \\
{ }^{*} \text { Clarity/diode laser } 2 \mathrm{~W} / \\
\mathrm{cm}^{2} / 3 \mathrm{~s}+\text { force } \\
{ }^{*} \text { Inspire ICE/diode laser } 2 \\
\mathrm{~W} / \mathrm{cm}^{2} / 3 \mathrm{~s}+\text { force } \\
{ }^{*} \text { Clarity/diode laser } 5 \mathrm{~W} / \\
\mathrm{cm}^{2} / 3 \mathrm{~s}+\text { force } \\
{ }^{*} \mathrm{Inspire} \mathrm{ICE} / \text { diode laser } 5 \\
\mathrm{~W} / \mathrm{cm}^{2} / 3 \mathrm{~s}+\text { force }\end{array}$ & $\begin{array}{l}\text { diode } \\
{ }^{* T}=3 \mathrm{~s} . \\
{ }^{*} \mathrm{E}=2 \& 5 \mathrm{~W} / \mathrm{cm}^{2}\end{array}$ & $\begin{array}{l}\text { *Monocrystalline + } \\
\text { polycrystalline } \\
\text { *Single-paste visible } \\
\text { light-cured orthodontic } \\
\text { adhesive system, } \\
\text { transbond XT }\end{array}$ & $\begin{array}{l}\text { The diode laser was ineffective with polycrystalline } \\
\text { brackets and efficient with monocrystalline brackets } \\
\text { in significantly }(P<0.05) \text { decreasing the shear bond } \\
\text { strength. } \\
\text { Diode laser irradiation significantly lowered the force } \\
\text { required for monocrystalline brackets to be removed } \\
\text { without increasing pulp temperature significantly. } \\
\text { Diode laser use did not significantly reduce the } \\
\text { debonding force required for polycrystalline brackets with } \\
\text { stainless steel slots. }\end{array}$ \\
\hline $\begin{array}{l}\text { Oztoprak et } \\
\mathrm{al}^{14}\end{array}$ & $\begin{array}{l}N=60 \\
2 \text { groups }\end{array}$ & $\begin{array}{l}\text { Er:YAG } \\
P=4.2 W \\
T=9 \mathrm{~s}\end{array}$ & $\begin{array}{l}\text { *Polycrystalline ceramic } \\
\text { bracket } \\
\text { *Orthodontic composite } \\
\text { adhesive transbond XT }\end{array}$ & $\begin{array}{l}\text { Statistically significant }(P=0.001) \text { lower shear bond } \\
\text { strengths were found in the laser group }(9.52 \mathrm{MPa}) \\
\text { compared with the control group ( } 20.75 \mathrm{MPa}) .\end{array}$ \\
\hline $\begin{array}{l}\text { Nalbantgil } \\
\text { et } a^{15}\end{array}$ & $\begin{array}{l}\text { *Part 1: } \mathrm{N}=80,4 \text { groups } \\
\text { *Control } \\
\text { *3 study groups (lasing for } \\
3,6,9 \mathrm{~s} .) \\
\text { *Part } 2: \mathrm{N}=30,3 \text { groups } \\
\text { (3, } 6 \text {, and } 9 \text { s of lasing } \\
\text { durations.) }\end{array}$ & $\begin{array}{l}\text { Er:YAG } \\
T=3,6,9 \mathrm{~s} . \\
P=4.2 \mathrm{~W} \\
W L=2940 \mathrm{~nm} . \\
E=140 \mathrm{~mJ} \\
F=30 \mathrm{~Hz} \\
D=2 \mathrm{~mm} .\end{array}$ & $\begin{array}{l}\text { *Polycrystalline alumina } \\
\text { brackets } \\
\text { *Orthodontic composite } \\
\text { adhesive transbond XT }\end{array}$ & $\begin{array}{l}\text { The results showed statistically significant differences } \\
\text { between the control and the study groups }(P<0.001) \text {. } \\
\text { The shear test exhibited significantly lower shear bond } \\
\text { strengths for the laser-irradiated groups. } \\
\text { When the shear bond strengths of the study groups } \\
\text { were compared within themselves, the only statistically } \\
\text { significant difference was found between the } 3 \mathrm{~s} \text { and } 9 \mathrm{~s} \\
\text { groups. }\end{array}$ \\
\hline $\begin{array}{l}\text { Tehranchi et } \\
\text { al }^{10}\end{array}$ & $\begin{array}{l}\mathrm{N}=30,2 \text { subgroups: } \\
{ }^{*} \text { Control } \\
\text { *Super pulse } \mathrm{CO}_{2} \text { laser }\end{array}$ & $\begin{array}{l}\mathrm{CO}_{2} \\
\mathrm{P}=50 \mathrm{~W} \\
\mathrm{~T}=5 \mathrm{~s} \\
\mathrm{~F}=400 \mathrm{~Hz}\end{array}$ & $\begin{array}{l}\text { *Chemically cured } \\
\text { orthodontic composite } \\
\text { resin } \\
{ }^{*} \text { Polycrystalline alumina }\end{array}$ & $\begin{array}{l}\text { Results of the shear bond strength in two subgroups } \\
\text { revealed that in the control group; teeth have definitely } \\
\text { higher values in comparison to the experimental group. }\end{array}$ \\
\hline Tozlu et al ${ }^{16}$ & $\begin{array}{l}\mathrm{N}=100,5 \text { groups } \\
{ }^{*} \text { Control } \\
\text { *4 experimental group: } \\
\text { laser+ Debonding } \\
\text { performed } 1 \mathrm{~s}, 18 \mathrm{~s}, 30 \mathrm{~s}, 60 \\
\mathrm{~s} \text { after laser exposure }\end{array}$ & $\begin{array}{l}\text { Er-YAG } \\
P=5 \mathrm{~W} \\
T=6 \mathrm{~s} \\
\mathrm{WL}=2,940 \mathrm{~nm} \\
\text { Tip diameter }=1 \\
\mathrm{~mm} . \\
\mathrm{D}=2 \mathrm{~mm}\end{array}$ & $\begin{array}{l}\text { * Polycrystalline ceramic } \\
\text { brackets } \\
\text { *Orthodontic composite } \\
\text { adhesive resin transbond } \\
\text { XT }\end{array}$ & $\begin{array}{l}\text { Statistically significant difference was found between } \\
\text { the control and experimental groups when the results } \\
\text { of the shear bond strengths were evaluated }(P<0.05) \text {. } \\
\text { The specimens that were irradiated with an Er-YAG laser } \\
\text { showed statistically significant lower shear bond strength } \\
\text { than control group }(P<0.001) \text {. As the time lag between } \\
\text { lasing and debonding increased, shear bond strengths } \\
\text { increased accordingly. }\end{array}$ \\
\hline $\begin{array}{l}\text { A. Sarp et al } \\
8 / 2011\end{array}$ & $\begin{array}{l}9 \text { groups } \\
\text { Control group: no lasing } \\
\text { Group2 : } 2 \mathrm{~W} \\
\text { Group3 : } 3 \mathrm{~W} \\
\text { Group4 :4W } \\
\text { Group5 : } 5 \mathrm{~W} \\
\text { Group6 : } 6 \mathrm{~W} \\
\text { Group } 200 / 600: P=18 \mathrm{~W} \\
\text {, on time }=200 \mathrm{~ms} \text {. off time } \\
600 \mathrm{~ms} \text {. } \\
\text { Group } 300 / 900 P=18 \mathrm{~W} \\
\text { Group } 400 / 1200 \mathrm{P}=18 \mathrm{~W}\end{array}$ & $\begin{array}{l}\text { ytterbium fiber } \\
\text { WL=1,070-nm } \\
{ }^{*} \text { continuous wave } \\
(\mathrm{CW}){ }^{*} \text { modulated } \\
\text { mode } \\
\text { current }=4.99 \mathrm{~A} . \\
\mathrm{P}=18 \mathrm{~W} .\end{array}$ & $\begin{array}{l}\text { *Polycrystalline ceramic } \\
\text { brackets } \\
\text { *chemically curing Bis- } \\
\text { GMA resin }\end{array}$ & $\begin{array}{l}\text { Debonding force and work done by a universal testing } \\
\text { machine were all significantly reduced for both modalities } \\
\text { of laser irradiation compared to the control group. } \\
\text { When laser parameters were set to proper doses, a 50\% } \\
\text { of decrease in required load for removal was found. } \\
\text { During debonding, the work done by the universal testing } \\
\text { machine is decreased up to five times by irradiation. } \\
\text { Modulated mode laser application (Group 300/900) } \\
\text { provided faster and easier debonding. } \\
\text { The mode of operation is as important as the wavelength } \\
\text { and the output power of the laser used. }\end{array}$ \\
\hline
\end{tabular}


Table 1. Continued

\begin{tabular}{|c|c|c|c|c|}
\hline $\begin{array}{l}\text { Dostalováa } \\
\text { et al }{ }^{17}\end{array}$ & $\begin{array}{l}\text { N }=80 \\
\text { 1. Ceramic bracket: } \\
\text { Fascination } 2 \\
\text { 2. Adhesive precoated } \\
\text { ceramic brackets Charity } \\
\text { SL APC } \\
\text { 3, 4. Twenty flat enamel } \\
\text { surfaces with brackets } \\
\text { fascination } 2 \text { and Charity } \\
\text { SL APC } \\
\text { *The teeth divided into } \\
\text { three groups } \\
\text { (1) P = } 1 \text { W; } \\
\text { (2) P = } 4 \text { W; } \\
\text { (3) Control group } \\
\text {-debonding without the } \\
\text { laser irradiation. }\end{array}$ & $\begin{array}{l}\text { Diode-pumped } \\
\text { Tm:YAP } \\
W L=1997 \mathrm{~nm} \\
\mathrm{P}=1,4 \mathrm{~W}\end{array}$ & $\begin{array}{l}\text { *Fascination } 2 \\
\text { (Dentaurum)-adhesive } \\
\text { pre-coated ceramic } \\
\text { brackets Charity SL APC } \\
\text { (3M Unitek Orthodontic } \\
\text { Products) } \\
\text { *1. ConTec LC adhesive } \\
\text { (Dentaurum) } \\
\text { 2. By selfetching primer } \\
\text { Transbond plus primer } \\
\text { (3M Unitek Orthodontic } \\
\text { Products). }\end{array}$ & $\begin{array}{l}\text { In the case of the } 1 \mathrm{~W} \text {. Tm:YAP laser power, the ceramic } \\
\text { bracket fascination } 2 \text { showed the significant decrease } \\
\text { adhesive resin strength about } 15 \mathrm{~N} \text { in comparison with } \\
\text { the control group (from } 64 \mathrm{~N} \text { to } 49 \mathrm{~N} \text { ). In the case of the } \\
\text { bracket Charity SL APC the decrease was } 5 \mathrm{~N} \text { only (from } \\
40 \mathrm{~N} \text { to } 35 \mathrm{~N} \text { ). } \\
\text { For } 4 \mathrm{~W} \mathrm{Tm} \text { :YAP laser power, the bracket debonding } \\
\text { was less effective. For the ceramic bracket fascination } \\
2 \text { the value of force reduced about } 6 \mathrm{~N} \text { only (from } 64 \mathrm{~N} \\
\text { to } 58 \mathrm{~N} \text { ). In the case of Charity SL APC, the bracket bond } \\
\text { between adhesive resin and enamel even increased (from } \\
40 \mathrm{~N} \text { to } 68 \mathrm{~N} \text { ). It was possibly caused by adhesive resin } \\
\text { hardening. }\end{array}$ \\
\hline $\begin{array}{l}\text { Almohaimeed } \\
\text { et } \mathrm{al}^{18}\end{array}$ & $\begin{array}{l}\mathrm{N}=80 \\
4 \text { groups } \\
\text { *APC II/laser: study g. } \\
\text { *APCII/No laser: control g. } \\
\text { *APC plus (precoated } \\
\text { ceramic brackets)/laser: } \\
\text { study g. } \\
\text { *APC plus (precoated } \\
\text { ceramic brackets)/No laser: } \\
\text { control g. }\end{array}$ & $\begin{array}{l}\text { Diode } \\
\text { *(Maximum energy } \\
25 \mathrm{~nm} \text {, pulse } \\
\text { duration } \mathrm{cW} \text { ) } \\
{ }^{* W L}=980 \mathrm{~nm} . \\
{ }^{*} \mathrm{P}=3 \mathrm{~W} . \\
{ }^{*} \mathrm{~T}=3 \mathrm{~s} .\end{array}$ & $\begin{array}{l}\text { *APCII } \\
\text { *APC Plus Adhesive Pre- } \\
\text { coated Ceramic bracket } \\
\text { *Cement: Transbond } \\
\text { Plus SEP }\end{array}$ & $\begin{array}{l}\text { Significantly }(P<0.001) \text { lower shear bond strengths were } \\
\text { observed in the laser groups compared with the control } \\
\text { groups. } \\
\text { Diode lasers effectively decrease the shear bond } \\
\text { strengths for precoated ceramic brackets because they } \\
\text { were effective in debonding ceramic brackets without } \\
\text { enamel damage or bracket fractures. }\end{array}$ \\
\hline $\begin{array}{l}\text { Ayano Saito } \\
\text { et }\left.a\right|^{11}\end{array}$ & $\begin{array}{l}\mathrm{N}=96,12 \text { groups } \\
\text { *Microcapsule contents }(0, \\
30 \text {, and } 40 \text { wt\%) } \\
\text { *Laser irradiation for } 4,5, \\
\text { and } 6 \mathrm{~s} \text {. }\end{array}$ & $\begin{array}{l}\mathrm{CO}_{2} \\
\mathrm{~T}=4,5,6 \mathrm{s.} .\end{array}$ & $\begin{array}{l}\text { *4 META/MMA-TBB resin } \\
\text { orthodontic adhesives } \\
\text { containing } 30 \text { and } 40 \\
\text { wt\% thermal expansion } \\
\text { microcapsules } \\
\text { *Zirconium ceramic }\end{array}$ & $\begin{array}{l}\text { Shear bond strengths around } 18 \mathrm{MPa} \text { without laser } \\
\text { irradiation did not change with laser irradiation for } 4-6 \mathrm{~s} \\
\text { when the adhesive did not contain microcapsules. On the } \\
\text { other hand, even if no laser irradiation was performed, } \\
\text { shear bond strength reduced to } 0.63 \text { - or } 0.75 \text {-fold by } \\
\text { addition of } 30 \text { or } 40 \text { wt\% microcapsules compared } \\
\text { with the adhesive with no microcapsules. With laser } \\
\text { irradiation, the bond strength of the } 30 \text { wt } \% \text { microcapsule } \\
\text { group irradiated for } 4 \mathrm{~s} \text { decreased to } 0.8 \text {-fold, and those } \\
\text { irradiated for } 5 \text { and } 6 \mathrm{~s} \text { were lowered to } 0.46 \text {-fold. The } \\
\text { bond strength in the } 40 \text { wt } \% \text { group was similar; a } 0.40- \\
0.48 \text {-fold decrease was observed. } \\
\text { Bond strength of the adhesive containing } 40 \text { wt } \% \\
\text { microcapsules was enough for orthodontic treatment and } \\
\text { was reduced significantly to } 0.40-0.48 \text {-fold ( } 4.65 .5 \mathrm{MPa} \text { ) } \\
\text { by } \mathrm{CO}_{2} \text { laser irradiation for } 5 \text { or } 6 \mathrm{~s} \text { versus the non-laser } \\
\text { groups. }\end{array}$ \\
\hline $\begin{array}{l}\text { Nalbantgil } \\
\text { et } \mathrm{al}^{19}\end{array}$ & $\begin{array}{l}\mathrm{N}=60 \\
\text { 1. Control group: no laser } \\
\text { 2. With water-cooling (water } \\
\text { group) } \\
\text { 3. Without water-cooling } \\
\text { (waterless group). }\end{array}$ & $\begin{array}{l}\text { Er:YAG } \\
P=5 W \\
W L=2940 \mathrm{~nm} \\
T=9 \mathrm{~s} \\
D=2 \mathrm{~mm}\end{array}$ & $\begin{array}{l}\text { *Polycrystalline ceramic } \\
\text { brackets (Transcend) } \\
\text { *Transbond XT }\end{array}$ & $\begin{array}{l}\text { The results exhibited statistically significant differences } \\
\text { between the control, water, and the waterless groups }(P< \\
0.05) \text {. The mean shear bond strength was } 22.76 \mathrm{MPa} \text { for } \\
\text { the control group, } 10.46 \mathrm{MPa} \text { for the water-cooled group, } \\
\text { and } 6.36 \mathrm{MPa} \text { for the waterless group, respectively. } \\
\text { Er-YAG laser-aided debonding, with or without water- } \\
\text { cooling, was efficient for debonding ceramic brackets by } \\
\text { lowering shear bond strength. }\end{array}$ \\
\hline Marci et al ${ }^{9}$ & $\begin{array}{l}\mathrm{N}=75 \\
12 \text { groups according to } \\
\text { different irradiation times } \\
\text { ( } 3 \text { and } 5 \mathrm{~s}) \text {, pulse duration } \\
(0.001 \text { and } 0.003 \mathrm{~s}) \text {, output } \\
\text { power }(5,8 \text {, and } 10 \mathrm{~W})\end{array}$ & $\mathrm{CO}_{2}$ & $\begin{array}{l}\text { *Polycrystalline ceramic } \\
\text { bracket (Fascination, } \\
\text { Dentaurum, Ispringen, } \\
\text { BW, Germany) } \\
\text { *Transbond Plus Self } \\
\text { Etching Primer (TPSEP, } \\
\text { 3M/Unitek, Monrovia, } \\
\text { CA, USA) }\end{array}$ & $\begin{array}{l}\text { Group IV (10 W, } 3 \mathrm{~s}, 0.01 \mathrm{~s}) \text { showed the lowest debonding } \\
\text { value, and the average was statistically lower versus other } \\
\text { groups. } \\
\text { The } \mathrm{CO}_{2} \text { laser reduced the bond strength without } \\
\text { increasing the temperature excessively. }\end{array}$ \\
\hline
\end{tabular}

Abbreviations: $n$ : sample size, WL: wave length, P: power, PP: peak power, T: time, D: distance from bracket, F: frequency, and E: energy.

for all lased groups were statistically significant and less than the $5.5^{\circ} \mathrm{C}$ increase threshold except for the group of monocrystalline bracket irradiated by $5 \mathrm{~W} / \mathrm{cm}^{2}$ in which mean pulp chamber increased more, but not significantly higher than the $5.5^{\circ} \mathrm{C}$ threshold. Ivanov et $\mathrm{al}^{21}$ also showed that $2.5 \mathrm{~W}$ diode laser irradiation for 6 seconds did not increase the pulp chamber temperature. In another study Dostalováa et $\mathrm{al}^{17}$ used 1997 nm longitudinally diode pumped Tm:YAP laser for debonding monocrys- talline and polycrystalline ceramic bracket and concluded that the temperature rise was safe in both bracket types. Nalbantgil et $\mathrm{al}^{15,19}$ used Er:YAG laser for bracket removal and observed that temperature increases for all specimens were below the $5.5^{\circ} \mathrm{C}$ benchmark. Sarp et $\mathrm{al}^{8}$ used 1070 $\mathrm{nm}$ ytterbium fiber laser and reported minimal intrapulpal temperature rise. Hayakawa et $\mathrm{al}^{12}$ used 1, 2 and $3 \mathrm{~J}$. of Nd:YAG laser for bracket removal and demonstrated that the increase in intrapulpal temperature was extremely low, 
Table 2. Studies Investigating Debonding Time of Laser Aided Ceramic Bracket Removal

\begin{tabular}{|c|c|c|c|c|}
\hline Author & Groups & Laser & Brackets Cement & Results /Conclusion \\
\hline Sarp et al ${ }^{8}$ & $\begin{array}{l}9 \text { groups } \\
\text { Control group: no lasing } \\
\text { Group 2: } 2 \mathrm{~W} \\
\text { Group 3: } 3 \mathrm{~W} \\
\text { Group 4: } 4 \mathrm{~W} \\
\text { Group 5: } 5 \mathrm{~W} \\
\text { Group 6: } 6 \mathrm{~W} \\
\text { Group 200/600 : P= } 18 \mathrm{~W} \text {, } \\
\text { on time }=200 \mathrm{~ms} \text {. off time } \\
600 \mathrm{~ms} \text {. } \\
\text { Group } 300 / 900 \mathrm{P}=18 \mathrm{~W} \\
\text { Group } 400 / 1200 \mathrm{P}=18 \mathrm{~W}\end{array}$ & $\begin{array}{l}\text { Ytterbium fiber } \\
\text { WL=1070-nm } \\
{ }^{*} \text { Continuous } \\
\text { wave }(\mathrm{CW}) \\
\text { *Modulated } \\
\text { mode } \\
\text { Current }=4.99 \\
\mathrm{~A} . \\
\mathrm{P}=18 \mathrm{~W} \text {. }\end{array}$ & $\begin{array}{l}\text { *Polycrystalline ceramic } \\
\text { brackets } \\
{ }^{*} \text { Chemical curing of Bis GMA resin }\end{array}$ & $\begin{array}{l}\text { Debonding time was significantly reduced } \\
\text { for both modalities of laser irradiation } \\
\text { compared to the control group. } \\
\text { When laser parameters were set to } \\
\text { proper doses a three-fold decrease in } \\
\text { debonding time was found. }\end{array}$ \\
\hline Saito et $\mathrm{al}^{11}$ & $\begin{array}{l}\mathrm{N}=96,12 \text { groups } \\
\text { *Microcapsule contents (0, } \\
30 \text {, and } 40 \text { wt } \%) \\
\text { *Laser irradiation for } 4, \\
5,6 \mathrm{~s}\end{array}$ & $\begin{array}{l}\mathrm{CO}_{2} \\
\mathrm{~T}=4,5,6 \mathrm{~s}\end{array}$ & $\begin{array}{l}\text { *4 META/MMA-TBB resin orthodontic } \\
\text { Adhesives (Orthomite Super Bond) } \\
\text { containing } 30 \text { and } 40 \mathrm{wt} \% \text { thermal } \\
\text { expansion microcapsules in the polymer } \\
\text { powder } \\
\text { *Zirconium ceramic }\end{array}$ & $\begin{array}{l}\text { The debonding times of } 5 \text { or } 6 \mathrm{~s} \text { were } 2 \\
\text { or } 3 \mathrm{~s} \text { shorter per tooth compared with } \\
\text { debonding using a traditional heater. }\end{array}$ \\
\hline
\end{tabular}

Abbreviations: $n$ : sample size, $\mathrm{WL}$ : wave length, $\mathrm{P}$ : power, PP: peak power, T: time, $\mathrm{D}$ : distance from bracket, $\mathrm{F}$ : frequency, and E: energy.

and the maximum temperature rise was $5.1^{\circ} \mathrm{C}$ (Table 3 ).

Laser Irradiation and Enamel Damage

Traditional bracket debonding is achieved by applying a sufficiently large force to break the bond. These forces may tear out the enamel. Enamel damage is also an important concern during laser aided ceramic bracket removal and has been investigated during different types of laser irradiation including $\mathrm{CO}_{2}$, Er:Yag, Nd:YAG and diode lasers (Table 4).

Ahrari et al $^{1}$ studied the risk of enamel damage during $\mathrm{CO}_{2}$ laser-aided ceramic bracket debonding. They measured the adhesive remnant index (ARI) and length, number and direction of enamel cracks. They showed that laser-aided debracketing can be done with minimal damage to tooth tissue and no bracket fracture was investigated (Table 5). Tehranchi et $\mathrm{al}^{10}$ also used $\mathrm{CO}_{2}$ laser for debracketing and observed more ARI on the tooth surface versus conventional methods. They demonstrated that according to ARI, the debonding site in the control group is closer to the enamel-adhesive interface and, consequently, the rate of enamel damage in this group is greater. Saito et $\mathrm{al}^{11}$ used experimentally produced 4 META/MMA-TBB resin orthodontic adhesives containing thermal expansion microcapsules for bracket bonding by $\mathrm{CO}_{2}$ laser and found no ARI significant differences among the groups. The adhesive remained on the brackets. Iijima et $\mathrm{al}^{2}$ investigated the effect of a $\mathrm{CO}_{2}$ laser on hardness and modulus of elasticity of enamel and found that $\mathrm{CO}_{2}$ laser debracketing may not cause iatrogenic damage to the enamel.

Oztoprak et al, ${ }^{14}$ Mundethu et $\mathrm{al}^{12}$ and Nalbantgil et $\mathrm{al}^{15}$ using Er:YAG for debonding showed a decreased risk of enamel damage via ARI measurements. Using SEM and light microscopy, Mundethu et $\mathrm{al}^{22}$ observed no damage to enamel surface. Tozlu et $\mathrm{a}^{16}$ also used Er:YAG laser for debonding, and the time lag between lasing and debonding differed between groups (1, 18, 30, and 60 seconds). They found that ARI scores of the groups were not statistically different.

Han et $\mathrm{al}^{3}$ used the Nd:YAG laser at $3 \mathrm{~W}$ for 3 seconds for debracketing. They found that laser irradiation had the best ARI scores. They concluded that the laser-aided technique induced little enamel scratch or loss.

Feldon et $\mathrm{al}^{13}$ and Almohaimeed et $\mathrm{al}^{18}$ used diode laser for debracketing. Their results of ARI score of lased and non-lased groups were different-this may be caused by different lasing powers or different brackets and cement.

\section{Discussion}

Adhesive resin degradation may occur through three processes: thermal softening, thermal ablation and photoablation. In the thermal softening process, the bonding agent is heated until it softens and the bracket slides off the tooth surface. Thermal ablation occurs when the temperature increases rapidly in an adhesive resin vaporization range. As a result, the bracket blows off the tooth surface before thermal softening occurs. In photoablation, the energy level of the bonds between the bonding-resin atoms rapidly increases above their dissociation energy levels resulting in the decomposition of the material. In comparison, thermal softening occurs at low power of densities - thermal ablation and photoablation occurs at high power densities. ${ }^{4}$

Different types of lasers such as Nd:YAG, Er:YAG, diode and Tm:YAP $\left(\mathrm{Tm}^{3+}\right.$ doped YAlO3) have been used for ceramic bracket debonding. Each of them has its own advantages. Some authors report that adhesive resin degradation by laser energy occurs when the wavelength transmits through the bracket materials. Thus, the carbon dioxide laser-whose wavelength is more easily absorbed by the ceramic brackets-has been chosen for debracketing in some studies. ${ }^{8}$ On the other hand it has been suggested that instead of the laser light being absorbed by the bracket and indirectly affecting the adhesive resin, direct application of the laser to the resin would enhance the effects of thermal ablation and photoablation. Thus, the Nd:YAG laser was selected in some studies because of its lower ceramic absorption level in comparison to carbon dioxide laser. ${ }^{12}$ The relatively small size, weight, power requirement, and lower cost make diode laser a practical addition to clinical practice. ${ }^{13}$ In other studies, the advantages of producing less thermal effects made the Er-YAG 
Table 3. Studies Investigating Pulpal Temperature Increase During Laser Aided Ceramic Bracket Removal

\begin{tabular}{|c|c|c|c|c|}
\hline Author & Groups & Laser & Brackets/Cement & Results/Conclusion \\
\hline $\begin{array}{l}\text { Hayakawa } \\
\text { et } \mathrm{al}^{12}\end{array}$ & $\begin{array}{l}\mathrm{n}=5 \\
\text { group 1: Single crystal } \\
\text { subgroup1, 2, 3, 4: MMA (Control, } 1 \mathrm{~J}, 2 \mathrm{~J}, 3 \mathrm{~J}) \\
\text { subgroup 5, 6, 7, 8: Bis-GMA (Control, } 1 \mathrm{~J}, 2 \\
\mathrm{~J}, 3 \mathrm{~J} \text { ) } \\
\text { group 2: polycrystal } \\
\text { subgroup 1, 2, } 3 \text {,4: MMA (Control, } 1 \mathrm{~J}, 2 \mathrm{~J}, 3 \mathrm{~J}) \\
\text { subgroup 5, 6, 7, 8: Bis-GMA (Control, } 1 \mathrm{~J}, 2 \\
\mathrm{~J}, 3 \mathrm{~J} \text { ) }\end{array}$ & $\begin{array}{l}\text { Nd:YAG } \\
W L=1060 \mathrm{~nm} \\
\mathrm{~F}=1-\text { pulse } / \mathrm{s} \\
\mathrm{E}=1,2,3 \mathrm{~J}\end{array}$ & $\begin{array}{l}\text { *Single crystal (Inspire), } \\
\text { polycrystalline (Clarity) } \\
\text { *4-META, MMA, Bis-GMA }\end{array}$ & $\begin{array}{l}\text { The increase in intrapulpal temperature } \\
\text { caused by lasing was extremely low, and the } \\
\text { maximum temperature increase was } 5.1^{\circ} \mathrm{C} \text {. }\end{array}$ \\
\hline $\begin{array}{l}\text { lijima } \\
\text { et } \mathrm{al}^{2}\end{array}$ & ${ }^{*} \mathrm{~N}=3$ to assess the temperature change & $\begin{array}{l}\mathrm{CO}_{2} \\
\mathrm{WL}^{2}=10.6 \mathrm{~mm} \\
\mathrm{~T}=5 \mathrm{~s} \\
\mathrm{P}=3,4,5,6 \mathrm{~W}\end{array}$ & $\begin{array}{l}\text { *Single-crystal brackets } \\
{ }^{*} \text { Conventional etch and } \\
\text { rinse adhesive System } \\
\text { transbond XT to assess the } \\
\text { temperature change }\end{array}$ & $\begin{array}{l}\text { The temperature of cross-sectioned enamel } \\
\text { increases by about } 200 \mathrm{C} \text { under } \mathrm{CO}_{2} \text { laser } \\
\text { irradiation with high output ( } 5 \text { and } 6 \mathrm{~W}) \text {, } \\
\text { while the temperature increases by about } \\
100 \mathrm{C} \text { to } 150 \mathrm{C} \text { under laser irradiation with } \\
\text { low output ( } 3 \text { and } 4 \mathrm{~W} \text { ). }\end{array}$ \\
\hline $\begin{array}{l}\text { Feldon et } \\
\mathrm{al}^{13}\end{array}$ & $\begin{array}{l}\mathrm{N}=60 \\
1^{*} \text { Clarity/Force only } \\
2^{*} \text { Inspire ICE/Force only } \\
3^{*} \text { Clarity/ Diode laser } 2 \mathrm{~W} / \mathrm{cm}^{2} / 3 \mathrm{~s} .+ \text { force } \\
4^{*} \text { Inspire ICE/ Diode laser } 2 \mathrm{~W} / \mathrm{cm}^{2} / 3 \mathrm{~s} .+ \text { force } \\
5^{*} \text { Clarity /Diode laser } 5 \mathrm{~W} / \mathrm{cm}^{2} / 3 \mathrm{~s} \text {. + force } \\
6^{*} \text { Inspire ICE/ Diode laser } 5 \mathrm{~W} / \mathrm{cm}^{2} / 3 \mathrm{~s} .+ \text { force }\end{array}$ & $\begin{array}{l}\text { diode } \\
{ }^{* T}=3 \mathrm{~s} . \\
* \mathrm{E}=2,5 \mathrm{~W} / \mathrm{cm}^{2}\end{array}$ & $\begin{array}{l}\text { *Monocrystalline(Inspire } \\
\text { ICE) + polycrystalline(clatiry) } \\
\text { *Single-paste visible light- } \\
\text { cured orthodontic adhesive } \\
\text { system, Transbond XT }\end{array}$ & $\begin{array}{l}\text { The mean rise in pulp chamber temperature } \\
\text { for groups } 3,4, \text { and } 5 \text { were statistically } \\
\text { significantly less }(P<0.01) \text { than the } 5.5^{\circ} \mathrm{C} \\
\text { increase threshold and not significantly } \\
\text { different }(P<0.01) \text { from the } 1.8^{\circ} \mathrm{C} \text { standard. } \\
\text { Group } 6 \text { had a mean pulp chamber increase } \\
\text { significantly greater than the } 1.8^{\circ} \mathrm{C} \text { standard } \\
\text { and not significantly different }(P<0.01) \text { from } \\
\text { the } 5.5^{\circ} \mathrm{C} \text { standard. }\end{array}$ \\
\hline $\begin{array}{l}\text { Nalbantgil } \\
\text { et al }{ }^{15}\end{array}$ & $\begin{array}{l}\text { *Part 2: } \\
\mathrm{N}=30,3 \text { groups }(3,6 \text {, and } 9 \mathrm{~s} \text { of lasing } \\
\text { durations.) }\end{array}$ & $\begin{array}{l}\text { Er:YAG } \\
T=3,6,9 \mathrm{~s} \\
P=4.2 \mathrm{~W} \\
\mathrm{WL}=2,940 \mathrm{~nm} . \\
E=140 \mathrm{~mJ} \\
\mathrm{~F}=30 \mathrm{~Hz} \\
D=2 \mathrm{~mm}\end{array}$ & $\begin{array}{l}\text { *Polycrystalline alumina } \\
\text { incisor brackets } \\
\text { *Orthodontic composite } \\
\text { adhesive Transbond XT }\end{array}$ & $\begin{array}{l}\text { The 3-s group showed a statistically } \\
\text { significantly lower rise in temperature than } \\
\text { the } 6-\mathrm{s} \text { and } 9 \text {-s groups. Likewise, the } 6-\mathrm{s} \\
\text { group exhibited a significantly lower rise than } \\
\text { the } 9 \text {-s group. } \\
\text { The temperature proportionally increased } \\
\text { with the extension of the lasing duration. } \\
\text { Temperature increases for all the three groups } \\
\text { remained below the } 5.5^{\circ} \mathrm{C} \text { benchmark. Six- } \\
\text { second lasing by the scanning method using } \\
\text { the Er:YAG laser was found to be the most } \\
\text { effective and safest way to remove ceramic } \\
\text { brackets without causing damage on enamel } \\
\text { and pulpal tissues. }\end{array}$ \\
\hline $\begin{array}{l}\text { Ahrari et } \\
\text { al }^{1}\end{array}$ & $\begin{array}{l}\mathrm{N}=90 \\
* \text { For temperature measurement }\end{array}$ & $\begin{array}{l}\mathrm{CO}_{2} \\
\mathrm{WL}=10.6 \mu \mathrm{m} \\
\mathrm{PP}=188 \mathrm{~W} \\
\mathrm{~F}=400 \mathrm{~Hz} \\
\mathrm{D}=5 \mathrm{~mm} \\
\mathrm{~T}=5 \mathrm{~s}\end{array}$ & $\begin{array}{l}\text { *Fascination polycrystalline } \\
\text { ceramic bracket ( features } \\
\text { chemical retention) } \\
\text { *Inspire Ice } \\
\text { (monocrystalline ceramic } \\
\text { bracket with mechanical } \\
\text { retention) } \\
\text { *Transbond XT adhesive }\end{array}$ & $\begin{array}{l}\text { Increase in intrapulpal temperatures below } \\
\text { the benchmark of } 5.5^{\circ} \mathrm{C} \text { for all the specimens. }\end{array}$ \\
\hline Sarp et $\mathrm{al}^{8}$ & $\begin{array}{l}9 \text { groups } \\
\text { Control group: no lasing } \\
\text { Group 2: } 2 \mathrm{~W} \\
\text { Group3: } 3 \mathrm{~W} \\
\text { Group4: } 4 \mathrm{~W} \\
\text { Group5: } 5 \mathrm{~W} \\
\text { Group 6: } 6 \mathrm{~W} \\
\text { Group 200/600: } \mathrm{P}=18 \mathrm{~W} \text {, on time = } 200 \\
\text { ms.off time } 600 \mathrm{~ms} \text {. } \\
\text { Group } 300 / 900 \mathrm{P}=18 \mathrm{~W} \\
\text { Group } 400 / 1200 \mathrm{P}=18 \mathrm{~W}\end{array}$ & $\begin{array}{l}\text { ytterbium fiber } \\
W L=1,070-n m \\
*^{*} \text { continuous } \\
\text { wave }(C W) \\
\text { *modulated } \\
\text { mode } \\
\text { current }=4.99 \\
\text { A.P }=18 \text { W. }\end{array}$ & $\begin{array}{l}\text { *Polycrystalline ceramic } \\
\text { brackets (G\&H, US) } \\
{ }^{*} \text { Chemically curing Bis-GMA } \\
\text { resin }\end{array}$ & $\begin{array}{l}\text { Intrapulpal temperature changes were lower } \\
\text { than the accepted threshold value }\left(5.5^{\circ} \mathrm{C}\right) \\
\text { until the level of } 3.5 \mathrm{~W} \text { of laser power in } \mathrm{CW} \\
\text { mode. Modulated mode laser application } \\
\text { (Group } 300 / 900) \text { provided faster and easier } \\
\text { debonding with less temperature change. } \\
\text { Minimal intrapulpal temperature change was } \\
\text { observed while removing ceramic brackets } \\
\text { with a } 1070 \text {-nm ytterbium fiber laser. }\end{array}$ \\
\hline
\end{tabular}

$\mathrm{N}=80$

1. Fascination $2+$ ConTec LC adhesive

2. Adhesive precoated ceramic brackets

Charity SL APC+ self etching primer Transbond

Dostalováa plus primer

$\begin{array}{ll}\text { Dostalováa } & 3,4.20 \text { flat enamel surfaces + brackets } \\ \text { et al17 } & \text { Fascination } 2 \text { and Charity SL APC }\end{array}$

Fascination 2 and Charity SL APC

*1. Fascination 2

Diodepumped 2. Precoated ceramic

Tm:YAP brackets Charity SL APC

$\mathrm{WL}=1997 \mathrm{~nm} \quad * 1$. ConTec $\mathrm{LC}$ adhesive

$\mathrm{P}=1,4 \mathrm{~W} \quad$ 2. Selfetching primer

Temperature increase was safe in both bracket types (Fascination $2-0.9^{\circ} \mathrm{C}$; Charity SL

*Three groups

2. Selfetching primer

APC $-0.7^{\circ} \mathrm{C}$ :for $\left.1 \mathrm{~W}\right)$

(1) $p=1 W$;
(2) $p=4 W$;

(3) Control group -debonding without laser

\begin{tabular}{|c|c|c|c|c|}
\hline $\begin{array}{l}\text { Saito et } \\
\mathrm{al}^{11}\end{array}$ & $\begin{array}{l}\mathrm{N}=96,12 \text { groups } \\
* \text { (Microcapsule contents }(0,30 \text {, and } 40 \mathrm{wt} \%) \\
* \text { Laser irradiation: } 4,5,6 \mathrm{~s}\end{array}$ & $\begin{array}{l}\mathrm{CO}_{2}: \\
P=3 \mathrm{~W} \\
\mathrm{D}=0 \mathrm{~mm} \\
\mathrm{~T}=4,5,6 \mathrm{~s}\end{array}$ & $\begin{array}{l}\text { *4 META/MMA-TBB resin } \\
\text { orthodontic Adhesives } \\
\text { containing } 30 \text { and } 40 \\
\text { wt\% thermal expansion } \\
\text { microcapsules in the } \\
\text { polymer powder } \\
\text { *Zirconium ceramic }\end{array}$ & $\begin{array}{l}\text { The temperature of the bracket base } \\
\text { exceeded } 80^{\circ} \mathrm{C} \text { with irradiation times of more } \\
\text { than } 4 \mathrm{~s} \text {. } \\
\text { All mean temperature increases in the pulp } \\
\text { chamber were less than } 4.3^{\circ} \mathrm{C} \text {. }\end{array}$ \\
\hline
\end{tabular}




\begin{tabular}{|c|c|c|c|c|}
\hline $\begin{array}{l}\text { Nalbantgil } \\
\text { et } \mathrm{al}^{19}\end{array}$ & $\begin{array}{l}\mathrm{N}=60 \\
\text { 1. Control group: no laser application } \\
\text { 2. With water-cooling (water group) } \\
\text { 3. Without water-cooling (waterless group). }\end{array}$ & $\begin{array}{l}\text { Er-YAG } \\
P=5 W \\
W L=2940 \mathrm{~nm} \\
T=9 \mathrm{~s} \\
D=2 \mathrm{~mm}\end{array}$ & $\begin{array}{l}\text { * Polycrystalline ceramic } \\
\text { brackets (Transcend, 3M } \\
\text { Unitek, Monrovia, CA, USA) } \\
\text { *Transbond XT }\end{array}$ & $\begin{array}{l}\text { A statistically significant difference was seen } \\
\text { in the mean temperature increases between } \\
\text { the groups }(P<0.05) \text {. The mean increases } \\
\text { were } 2.41 \mathrm{C} \text { and } 4.59 \mathrm{C} \text { with standard } \\
\text { deviations of } 0.25 \mathrm{C} \text { and } 0.48 \mathrm{C} \text { for the water } \\
\text { and waterless laser groups, respectively. }\end{array}$ \\
\hline $\begin{array}{l}\text { Marci et } \\
\mathrm{al}^{9}\end{array}$ & $\begin{array}{l}\mathrm{N}=30 \\
12 \text { groups according to } \\
\text { Different irradiation times ( } 3 \text { and } 5 \mathrm{~s}) \text {, pulse } \\
\text { duration }(0.001 \text { and } 0.003 \mathrm{~s}) \text {, output power ( } 5 \text {, } \\
8 \text {, and } 10 \mathrm{~W})\end{array}$ & $\mathrm{CO}_{2}$ & $\begin{array}{l}\text { *polycrystalline ceramic } \\
\text { bracket (Fascination, } \\
\text { Dentaurum, Ispringen, BW, } \\
\text { Germany) } \\
\text { *Transbond Plus Self } \\
\text { Etching Primer (TPSEP, } \\
\text { 3M/Unitek, Monrovia, CA, } \\
\text { USA) }\end{array}$ & $\begin{array}{l}\mathrm{CO}_{2} \text { laser may aid removal of ceramic brackets; } \\
\text { it reduced the bond strength without } \\
\text { increasing the temperature excessively. }\end{array}$ \\
\hline
\end{tabular}

Abbreviations: $n$ : sample size, WL: wave length, P: power, PP: peak power, T: time, D: distance from bracket, F: frequency, and E: energy.

Table 4. Studies Investigating Enamel Damage During Laser-Aided Ceramic Bracket Removal

\begin{tabular}{|c|c|c|c|c|}
\hline Author & Groups & Laser & Brackets Cement & Results/Conclusion \\
\hline Han et $\mathrm{al}^{3}$ & $\begin{array}{l}\mathrm{N}=30,3 \text { groups } \\
\text { (1) metallic brackets }+ \\
\text { shear debonding force } \\
\text { (2) Ceramic brackets }+ \\
\text { shear debonding force } \\
\text { (3) Ceramic brackets + } \\
\text { Nd:YAG laser irradiation }\end{array}$ & $\begin{array}{l}\text { Nd:YAG } \\
\text { WL = } 1060 \\
\mathrm{~nm} \\
\mathrm{P}=3 \mathrm{~W} . \\
\mathrm{T}=3 \mathrm{~s} . \\
\mathrm{D}=1 \mathrm{~mm} .\end{array}$ & $\begin{array}{l}\text { Metallic(MBT)/ } \\
\text { polycrystalline ceramic } \\
\text { brackets(Clarity) } \\
\text {-cement: NM }\end{array}$ & $\begin{array}{l}\text { Laser irradiation produces the most desired ARI scores. ARI scores } \\
\text { for group } 3 \text { was significantly lower than group } 2 \text {. } \\
\text { Laser-aided technique induced little enamel damage. }\end{array}$ \\
\hline Oztoprak et $\mathrm{al}^{19}$ & $\begin{array}{l}\mathrm{N}=60,2 \text { groups } \\
* \text { Laser } \\
* \text { Control }\end{array}$ & $\begin{array}{l}\text { Er:YAG } \\
P=4.2 \mathrm{~W} \\
\mathrm{~T}=9 \mathrm{~s}\end{array}$ & $\begin{array}{l}\text { *Polycrystalline } \\
\text { ceramic bracket } \\
\text { *Orthodontic } \\
\text { composite adhesive } \\
\text { Transbond XT/light } \\
\text { cure }\end{array}$ & $\begin{array}{l}\text { The laser group had twice as many samples with adhesive, } \\
\text { with the adhesive remnant index scores of } 2 \text { or } 3 \text {. A negative } \\
\text { correlation was found between bond strengths and ARI scores } \\
(P<0.001) \text {. As the shear bond strengths reduced, the ARI scores } \\
\text { increased. } \\
\text { Er:YAG laser use increased the ARI scores and thus decreased the } \\
\text { risk of enamel fracture. }\end{array}$ \\
\hline $\mid$ lijimaet $\left.a\right|^{2}$ & $\begin{array}{l}* \mathrm{~N}=50,10 \text { groups } \\
\text { (forshear bond strength \& } \\
\text { nanoindentation test) }\end{array}$ & $\begin{array}{l}\mathrm{CO}_{2} \\
\mathrm{WL}=10.6 \mathrm{~mm} \\
T=5 \mathrm{~s} . \\
P=3,4,5 \\
6 \mathrm{~W} .\end{array}$ & $\begin{array}{l}\text { * Single-crystal brackets } \\
\text { *Conventional etch } \\
\text { and rinse adhesive } \\
\text { system self-etching } \\
\text { adhesive system } \\
\text { transbond plus (for } \\
\text { measurements of } \\
\text { shear bond strength \& } \\
\text { nanoindentation test }\end{array}$ & $\begin{array}{l}\text { The hardness and elastic modulus of enamel were not affected by } \\
\mathrm{CO}_{2} \text { laser debonding. } \\
\mathrm{CO}_{2} \text { laser debonding may not induce iatrogenic damage to } \\
\text { enamel. }\end{array}$ \\
\hline Nalbantgil et al ${ }^{15}$ & $\begin{array}{l}\text { *Part 1: (shear test and } \\
\text { ARI) } \\
\mathrm{N}=80 \text {, } 4 \text { groups } \\
{ }^{*} \text { Control } \\
\text { *Lasing time: } 3,6,9 \mathrm{~s} .\end{array}$ & $\begin{array}{l}\text { Er:YAG } \\
T=3,6,9 \mathrm{~s} \\
P=4.2 \mathrm{~W} \\
\mathrm{WL}=2940 \\
\mathrm{~nm} \\
\mathrm{E}=140 \mathrm{~mJ} \\
\mathrm{~F}=30 \mathrm{~Hz} \\
\mathrm{D}=2 \mathrm{~mm}\end{array}$ & $\begin{array}{l}\text { *polycrystalline } \\
\text { alumina incisor } \\
\text { brackets } \\
\text { *orthodontic } \\
\text { composite adhesive } \\
\text { Transbond } \\
\text { XT }\end{array}$ & $\begin{array}{l}\text { When ARI scores of the groups were compared, statistically } \\
\text { significant differences were observed between the 9-s study } \\
\text { group and control and 6-s study groups. } \\
\text { In all of the three study groups, the ARI scores increased as the } \\
\text { shear bond strengths reduced. Six-second lasing by the scanning } \\
\text { method using the Er:YAG laser was showed to be the most } \\
\text { effective and safest way to remove ceramic brackets without } \\
\text { causing damage on enamel and pulpal tissues. }\end{array}$ \\
\hline Feldon et $\mathrm{al}^{13}$ & 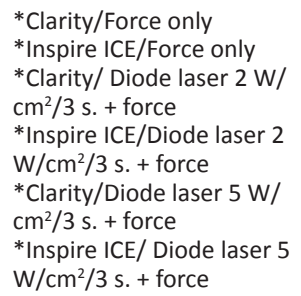 & $\begin{array}{l}\text { diode } \\
* \mathrm{~T}=3 \mathrm{~s} \\
{ }^{*} \mathrm{E}=2 \& 5 \mathrm{~W} / \\
\mathrm{cm}^{2}\end{array}$ & $\begin{array}{l}\text { *Monocrystalline + } \\
\text { polycrystalline } \\
\text { *Single-paste visible } \\
\text { light-cured orthodontic } \\
\text { adhesive system, } \\
\text { Transbond XT }\end{array}$ & $\begin{array}{l}\text { There was no significant adhesive remnant index score } \\
\text { differences between any groups tested. All groups in the study } \\
\text { had mean ARI scores of } 3 \text {; this indicates that almost all adhesive } \\
\text { was left behind on the tooth surfaces with a clear imprint of } \\
\text { bracket base. } \\
\text { The use of the diode laser did not change the amount of adhesive } \\
\text { remaining on the tooth surface after debonding. }\end{array}$ \\
\hline Tozlu et al ${ }^{16}$ & $\begin{array}{l}\mathrm{N}=100,5 \text { groups } \\
{ }^{*} \text { Control } \\
{ }^{*} 4 \text { experimental g: laser+ } \\
\text { Debonding performed } 1 \\
\mathrm{~s}, 18 \mathrm{~s}, 30 \mathrm{~s} \text {, or } 60 \mathrm{~s} \text { after } \\
\text { laser exposure }\end{array}$ & $\begin{array}{l}\text { Er-YAG } \\
P=5 \mathrm{~W} \\
T=6 \mathrm{~s} \\
\mathrm{WL}=2940 \\
\mathrm{~nm} \\
\mathrm{D}=2 \mathrm{~mm}\end{array}$ & $\begin{array}{l}\text { *Polycrystalline } \\
\text { ceramic brackets } \\
\text { orthodontic } \\
{ }^{*} \text { Composite adhesive } \\
\text { resin Transbond XT }\end{array}$ & $\begin{array}{l}\text { Adhesive remnant index scores of the groups were not } \\
\text { statistically different }(P>0.05) \text {. } \\
\text { The control group had a score of " } 0 \text { " in a sample. This data } \\
\text { indicates that the debonding site was between the enamel and } \\
\text { the adhesive. Most of the specimens of the } 1 \text {-s and } 18-\mathrm{s} \text { group } \\
\text { had ARI scores of } 2 \text { or } 3 \text {; this showed that most of the adhesive } \\
\text { was left behind on the tooth surface. } \\
\text { The reduced shear bonds strengths increased along with the } \\
\text { extension of period of time between lasing and debonding. After } \\
6 \text { s of lasing with Er-YAG laser with the scanning method, the } 18-\mathrm{s} \\
\text { time lag to debond is ideal; however, care should be taken not to } \\
\text { exceed this limit. }\end{array}$ \\
\hline
\end{tabular}




\begin{tabular}{|c|c|c|c|}
\hline Tehranchi et al ${ }^{10}$ & $\begin{array}{l}\mathrm{N}=30,2 \text { subgroups: } \\
* \text { Control or no-lased } \\
* \text { Super pulse } \mathrm{CO}_{2} \text { laser }\end{array}$ & $\begin{array}{l}\mathrm{CO}_{2} \\
\mathrm{P}=50 \mathrm{~W} \\
\mathrm{~T}=5 \mathrm{~s} \\
\mathrm{~F}=400 \mathrm{~Hz}\end{array}$ & $\begin{array}{l}{ }^{*} \text { Chemically-cured } \\
\text { orthodontic composite } \\
\text { resin } \\
\text { *Polycrystalline } \\
\text { alumina }\end{array}$ \\
\hline
\end{tabular}

\begin{tabular}{|c|c|c|c|}
\hline Ahrari et al ${ }^{1}$ & $\begin{array}{l}\text { *N }=80,4 \text { groups (for } \\
\text { enamel damage) } \\
{ }^{*} \text { Group } \mathrm{CC}=\text { chemical } \\
\text { retention/conventional } \\
\text { debonding } \\
{ }^{*} \text { Group } \mathrm{MC}=\text { mechanical } \\
\text { retention/conventional } \\
\text { debonding } \\
{ }^{*} \text { Group } \mathrm{CL}=\text { chemical } \\
\text { retention/laser debonding } \\
\text { *Group } \mathrm{ML}=\text { mechanical } \\
\text { retention/laser debonding }\end{array}$ & $\begin{array}{l}\mathrm{CO}_{2} \\
\mathrm{WL}^{2}=10.6 \mu \mathrm{m} \\
\mathrm{PP}=188 \mathrm{~W} \\
\mathrm{~F}=400 \mathrm{~Hz} \\
\mathrm{D}=5 \mathrm{~mm} \\
\mathrm{t}=5 \mathrm{~s} .\end{array}$ & $\begin{array}{l}\text { *Fascination } \\
\text { polycrystalline ceramic } \\
\text { bracket (features } \\
\text { chemical retention) } \\
{ }^{*} \text { Inspire Ice a } \\
\text { monocrystalline } \\
\text { ceramic bracket( with } \\
\text { mechanical retention) } \\
\text { *Transbond XT } \\
\text { adhesive }\end{array}$ \\
\hline
\end{tabular}

\begin{tabular}{|c|c|c|}
\hline Mundethu et al ${ }^{22} \quad \mathrm{~N}=20$ & $\begin{array}{l}\text { Er:YAG } \\
E=600 \mathrm{~mJ} \\
\mathrm{~F}=2 \mathrm{~Hz} \\
\mathrm{WL}=2.94 \mu \mathrm{m}\end{array}$ & $\begin{array}{l}\text { *Blugloo adhesive } \\
\text { system } \\
\text { *Fully polycrystalline } \\
\text { bracket system(Damon } \\
\text { Clear;Ormco Corp, } \\
\text { Orange, CA, USA) }\end{array}$ \\
\hline
\end{tabular}

\begin{tabular}{|c|c|c|c|c|}
\hline Saito et $\mathrm{al}^{11}$ & $\begin{array}{l}N=96,12 \text { groups } \\
* \text { (microcapsule contents } \\
(0,30 \text {, and } 40 \text { wt } \%) \\
* \text { Laser irradiation for } 4,5, \\
\text { and } 6 \mathrm{~s}\end{array}$ & $\begin{array}{l}\mathrm{CO}_{2} \text { Laser: } \\
\mathrm{T}=4,5,6 \mathrm{~s} .\end{array}$ & $\begin{array}{l}\text { *4 META/MMA-TBB } \\
\text { resin orthodontic } \\
\text { Adhesives containing } \\
30 \text { and } 40 \text { wt\% } \\
\text { thermal expansion } \\
\text { microcapsules } \\
\text { *Zirconium ceramic }\end{array}$ & $\begin{array}{l}\text { Although the adhesive tended to remain on the brackets, no } \\
\text { significant differences were detected among the groups. }\end{array}$ \\
\hline $\begin{array}{l}\text { Almohaimeed } \\
\text { et } \mathrm{al}^{18}\end{array}$ & $\begin{array}{l}\mathrm{N}=80 \text { /4 groups: } \\
\text { *APC II/laser } \\
\text { *APCII/No laser (control) } \\
\text { *APC plus (precoated } \\
\text { ceramic brackets)/laser } \\
\text { *APC plus (precoated } \\
\text { ceramic brackets)/No } \\
\text { laser: (control) }\end{array}$ & $\begin{array}{l}\text { Diode } \\
* \mathrm{WL}=980 \mathrm{~nm} . \\
{ }^{*} \mathrm{P}=3 \mathrm{w} . \\
{ }^{*} \mathrm{~T}=3 \mathrm{~s} .\end{array}$ & $\begin{array}{l}\text { *APCII } \\
\text { *APC Plus Adhesive } \\
\text { Pre-Coated Ceramic } \\
\text { upper } \\
\text { premolar brackets } \\
\text { *Cement: Transbond } \\
\text { Plus SEP (Self-Etching } \\
\text { Primer - 3M Unitek, } \\
\text { Miami, FL, USA) }\end{array}$ & $\begin{array}{l}\text { The adhesive remnant index scores were significantly different ( } p \\
<0.001) \text {; the laser group had nearly twice as much adhesive with } \\
\text { ARI scores of } 2 \text { or } 3 \text {. } \\
\text { A negative correlation was found between bond strengths and } \\
\text { ARI scores }(p<0.001) \text {. The ARI scores increased as the shear } \\
\text { bond strengths decreased. }\end{array}$ \\
\hline Marci et al ${ }^{9}$ & $\begin{array}{l}\mathrm{N}=75 \\
12 \text { groups according to } \\
\text { different irradiation times } \\
(3 \text { and } 5 \mathrm{~s}) \text {, pulse duration } \\
(0.001 \text { and } 0.003 \mathrm{~s}) \text {, } \\
\text { output power }(5,8 \text {, and } \\
10 \mathrm{~W})\end{array}$ & $\mathrm{CO}_{2}$ & $\begin{array}{l}\text { *Polycrystalline } \\
\text { ceramic bracket } \\
\text { (Fascination, } \\
\text { Dentaurum, Ispringen, } \\
\text { BW, Germany) } \\
\text { *Transbond Plus Self } \\
\text { Etching Primer (TPSEP, } \\
\text { 3M/Unitek, Monrovia, } \\
\text { CA, USA) }\end{array}$ & The groups did not differ significantly in terms of ARI scores. \\
\hline
\end{tabular}

Abbreviations: $n$ : sample size, WL: wave length, P: power, PP: peak power, T: time, D: distance from bracket, F: frequency, and E: energy.

laser ideal versus Nd-YAG or $\mathrm{CO}_{2}$ lasers. ${ }^{23}$

The Er-YAG laser emits at $2904 \mathrm{~nm}$, which corresponds to the main absorption peak of water. ${ }^{24}$ Therefore, an ErYAG laser may be highly absorbed by the adhesive bonding resin containing water or residual monomer. ${ }^{19} \mathrm{Ad}-$ vantages of ytterbium fiber laser are high optical quality, compact size, extended lifetime and flexible mode of operation. Thus, it was selected for ceramic bracket remov-

No substantial differences with respect to the surface of debonding, which was mostly within the adhesive.

The results of ARI showed a significant difference between the control and study group. (This index denoted that the debonding site in the control group is closer to the enamel-adhesive interface and, consequently, the rate of enamel damage in this group will be greater.)

No case of enamel fracture was seen in the groups of ceramic brackets debonded with the aid of laser light.

The increase in the lengths of enamel cracks after debonding was statistically significant in all groups.

The number of cracks increased significantly in all groups after debonding $(P<0.05)$ (significant difference between conventional and laser debondings for both types of brackets.)

The number of pronounced cracks also increased significantly in all groups following debonding with the exception of ML group. Significant correlation was observed between the directions of enamel cracks before bonding and after bracket removal.

Significant difference in the distribution of ARI scores among the groups.

For each type of bracket, laser debonding caused a significant decrease in the number of cracks and an insignificant decrease in the length of cracks compared to debonding with pliers. Therefore, laser debonding can decrease the risk of enamel damage following removal of ceramic brackets.

The laser-debonded specimens had a lower frequency of ARI score 0 than conventional debonding groups, indicating a minimized probability of enamel damage.

The ARI score was 3 for all specimens.

The enamel surface of the tooth whose bracket was debonded in a single laser pulse exibited no laser-related morphological changes. The cross-sectional image revealed that the single laser pulse caused a minor removal of adhesive material at its surface at $100 x$ magnification. (The removed material left a shallow crater of a depth of $100-120 \mu \mathrm{m}$ with its base resting well within the adhesive. No crater extended into the underlying enamel.

SEM and light microscopy showed no damages to the enamel ARI scores of 2 or 3.

A negative correlation was found between bond strengths and ARI scores $(p<0.001)$. The ARI scores increased as the shear bond strengths decreased.

(1) 
Table 5. Studies Investigating Bracket Failure During Laser-Aided Ceramic Bracket Removal

\begin{tabular}{|c|c|c|c|c|}
\hline Author & Groups & Laser & Brackets Cement & Results Conclusion \\
\hline $\begin{array}{l}\text { Oztoprak } \\
\text { et al }{ }^{14}\end{array}$ & $\begin{array}{l}\mathrm{N}=60 \\
2 \text { groups }\end{array}$ & $\begin{array}{l}\text { Er:YAG } \\
P=4.2 \mathrm{~W} \\
T=9 \mathrm{~s}\end{array}$ & $\begin{array}{l}\text { *polycrystalline ceramic bracket } \\
\text { *orthodontic composite adhesive } \\
\text { Transbond XT }\end{array}$ & No bracket fractures \\
\hline $\begin{array}{l}\text { Ahrari et } \\
\text { al }^{1}\end{array}$ & $\begin{array}{l}* n=80,4 \text { groups for enamel damage } \\
{ }^{*} \text { Group } \mathrm{CC}=\text { chemical retention/ } \\
\text { conventional debonding) } \\
{ }^{*} \text { Group } \mathrm{MC}=\text { mechanical retention/ } \\
\text { conventional debonding } \\
{ }^{*} \text { Group } \mathrm{CL}=\text { chemical retention/laser } \\
\text { debonding } \\
{ }^{*} \text { Group } \mathrm{ML}=\text { mechanical retention/laser } \\
\text { debonding }\end{array}$ & $\begin{array}{l}\mathrm{Co}_{2} \\
W L=10.6 \mu \mathrm{m} \\
P P=188 \mathrm{~W} \\
\mathrm{~F}=400 \mathrm{~Hz} \\
\mathrm{D}=5 \mathrm{~mm} \\
\mathrm{~T}=5 \mathrm{~s}\end{array}$ & $\begin{array}{l}\text { *Fascination polycrystalline } \\
\text { ceramic bracket (features chemical } \\
\text { retention) } \\
\text { *Inspire Ice a monocrystalline } \\
\text { ceramic bracket (with mechanical } \\
\text { retention) } \\
\text { *Transbond XT adhesive }\end{array}$ & $\begin{array}{l}\text { No bracket fracture } \\
\text { Bracket fracture was found in } 45 \% \\
\text { of chemical retention, and } 15 \% \\
\text { of mechanical retention groups } \\
\text { debonded with pliers. There were no } \\
\text { cases of bracket fracture in the laser- } \\
\text { debonded groups. }\end{array}$ \\
\hline $\begin{array}{l}\text { Mundethu } \\
\text { et } \mathrm{al}^{22}\end{array}$ & $N=20$ & $\begin{array}{l}\text { Er:YAG } \\
E=600 \mathrm{~mJ} \\
\mathrm{WL}=2.94 \mu \mathrm{m}\end{array}$ & $\begin{array}{l}\text { *Blugloo adhesive system } \\
\text { *Fully polycrystalline bracket system } \\
\text { (Damon Clear) }\end{array}$ & No bracket failures. \\
\hline
\end{tabular}

Abbreviations: $n$ : sample size, WL: wave length, P: power, PP: peak power, T: time, D: distance from bracket, F: frequency, and E: energy.

perature increase causes no damage, but $5.5^{\circ} \mathrm{C}$ temperature increase could cause pulp necrosis in $15 \%$ of teeth. Different adhesive resins need different softening temperatures. Rueggeberg and Lockwood found that the temperature required to soften adhesive resins and thus reduce their bonding strengths depends on the type of adhesive and ranges from $44^{\circ} \mathrm{C}$ to $228^{\circ} \mathrm{C}$. As thermal pulpal irritation is possible during laser-aided debonding, the method and duration of the laser pulse must be exactly defined according to the adhesive resin type.

Another consideration is the temperature of the heated brackets. To adequately soften the adhesive resin, the surface temperature of a bracket reaches $150^{\circ} \mathrm{C}$. During laser debonding, continuous forces must be applied and the bracket must be removed immediately after adhesive resin softening to avoid pulpal tissue damage. ${ }^{12}$

Kim et $\mathrm{al}^{25}$ investigated the histomorphological effects of Nd:YAG laser and reported that debonding facilitated by a Nd:YAG laser at 7-13 W for $<5$ seconds caused mild and reversible changes in the histologic section of pulp. All results were reversible and no pulpal degeneration or necrosis occurred. In another study, Liu et $\mathrm{al}^{26}$ applied Nd:YAG laser at $3 \mathrm{~W}$ for 3 seconds, $2 \mathrm{~W}$ for 5 seconds and $5 \mathrm{~W}$ for 2 seconds-they found that a Nd:YAG laser of high energy may cause injury of the pulp tissue during debonding. The laser energy of $3 \mathrm{~W}$ for 3 seconds could effectively be used for ceramic bracket removal without irreversible pulp injury.

An important consideration in pulpal temperature increase is the type of bracket to be removed. Feldon et $\mathrm{al}^{13}$ debonded monocrystalline and polycrystalline ceramic brackets with a diode laser and reported that the mean increases in pulp chamber temperature for all lased groups were statistically significant and less than the $5.5^{\circ} \mathrm{C}$ increase threshold. It was not significantly different from the $1.8^{\circ} \mathrm{C}$ standard except for monocrystalline brackets irradiated by $5 \mathrm{~W} / \mathrm{cm}^{2}$ in which the mean pulp chamber increases significantly above the $1.8^{\circ} \mathrm{C}$ standard, but not significantly different from the $5.5^{\circ} \mathrm{C}$ standard. Ivanov et $\mathrm{al}^{21}$ also used a diode laser and observed that the debond- ing of polycrystalline brackets was cooler than monocrystalline brackets. They mentioned that the difference in the designs of the two brackets might be responsible for the differences in the intrapulpal temperatures of the two bracket types.

Other determinants of pulpal temperature increase are irradiation time, lasing mode, lasing method and water-cooling. ${ }^{8,15,19}$ As shown by Nalbantgil et al, ${ }^{15}$ the temperature proportionally increased as a function of laser irradiation time. They reported that lasing via a scanning approach was the most effective and safest way to debond ceramic brackets without causing injury to pulpal tissues. According to their investigation, the Er-YAG laser application with water-cooling was safer because it reduced the probability of intrapulpal temperature increase while debonding ceramic brackets.

Sarp et $\mathrm{al}^{8}$ used a 1070-nm ytterbium fiber laser with two lasing modes: CW (different constant power levels) and modulated mode (laser energy delivered with on-and-off cycles at $18 \mathrm{~W}$ ). They concluded that modulated mode laser application provides faster and easier debonding with less temperature change than $\mathrm{CW}$ mode. Therefore, we note that the mode of operation is as important as the wavelength and output power of the laser.

Other considerations in the use of laser-aided ceramic bracket removal are the potential risk of enamel damage. Many methods have been used to investigate enamel damage during laser-assisted ceramic bracket removal. These include ARI measurements (ARI), length, number and direction of enamel cracks, nano indentation test, SEM and light microscopy.

He and Swain used the nano indentation test to define the effects of heat treatment $\left(300^{\circ} \mathrm{C}\right)$ on the mechanical properties of enamel. They showed that the protein matrix and water within burnt enamel were damaged and removed, and the hardness and elastic modulus of heat-treated enamel were affected dramatically. ${ }^{2}$ According to Iijima et $\mathrm{al}^{2}$ the temperature of cross-sectioned enamel increases by about $200^{\circ} \mathrm{C}$ under $\mathrm{CO}_{2}$ laser irradiation with a relatively high output during debracketing-the temperature 
increases by about $100^{\circ} \mathrm{C}$ to $150^{\circ} \mathrm{C}$ under laser irradiation with low output.

On the basis of the nano indentation study by $\mathrm{He}$ and Swain, Iijima et $\mathrm{al}^{2}$ investigated the effect of $\mathrm{CO}_{2}$ laser on hardness and modulus of elasticity of enamel-they found that the $\mathrm{CO}_{2}$ laser debracketing may not cause iatrogenic damage to enamel. In comparison to conventional debracketing techniques in which bracket failure occurs $10 \%-35 \%^{5}$ or $15 \%-45 \%^{1}$ of the time, no bracket failure has been reported during laser-aided ceramic bracket removal.

\section{Conclusion}

Within the limitations of the present study, we conclude that irradiation of Nd:YAG, Er:YAG, $\mathrm{CO}_{2}$, Tm:Yap, diode or ytterbium fiber lasers may be considered as an efficient way to reduce shear bond strength of ceramic bracket and debonding time. This technique is a safe way for removing ceramic brackets while the intrapulpal temperature and enamel surface were minimally affected, along with reduced ceramic bracket failure.

\section{Conflict of Interest}

The author has no conflict of interest to declare.

\section{References}

1. Ahrari F, Heravi F, Fekrazad R, Farzanegan F, Nakhaei S. Does ultra-pulse CO2 laser reduce the risk of enamel damage during debonding of ceramic brackets? Lasers Med Sci. 2012;27(3):567-574. doi:10.1007/s10103-011-0933-y.

2. Iijima M, Yasuda Y, Muguruma T, Mizoguchi I. Effects of $\mathrm{CO} 2$ laser debonding of a ceramic bracket on the mechanical properties of enamel. Angle Orthod. 2010;80(6):10291035. doi:10.2319/041210-204.1.

3. Han X, Liu X, Bai D, Meng Y, Huang L. Nd: YAG laser-aided ceramic brackets debonding: effects on shear bond strength and enamel surface. Applied Surface Science. 2008;255(2):613-615. doi:10.1016/j.apsusc.2008.06.082.

4. Tocchio RM, Williams PT, Mayer FJ, Standing KG. Laser debonding of ceramic orthodontic brackets. Am J Orthod Dentofacial Orthop. 1993;103(2):155-162. doi:10.1016/ s0889-5406(05)81765-2.

5. Strobl K, Bahns TL, Wiliham L, Bishara SE, Stwalley W. Laser-aided debonding of orthodontic ceramic brackets. Am J Orthod Dentofacial Orthop. 1992;101(2):152-158. doi:10.1016/0889-5406(92)70007-w.

6. Mimura H, Deguchi T, Obata A, Yamagishi T, Ito M. Comparison of different bonding materials for laser debonding. Am J Orthod Dentofacial Orthop. 1995;108(3):267-273. doi:10.1016/s0889-5406(95)70020-x.

7. Ma T, Marangoni RD, Flint W. In vitro comparison of debonding force and intrapulpal temperature changes during ceramic orthodontic bracket removal using a carbon dioxide laser. Am J Orthod Dentofacial Orthop. 1997;111(2):203-210. doi:10.1016/s0889-5406(97)70217-8.

8. Sarp ASK, Gülsoy M. Ceramic bracket debonding with ytterbium fiber laser. Lasers Med Sci. 2011;26(5):577-584. doi:10.1007/s10103-010-0817-6.

9. Macri RT, de Lima FA, Bachmann L, et al. CO laser as auxiliary in the debonding of ceramic brackets. Lasers Med Sci. 2014. doi:10.1007/s10103-014-1688-z.
10. Tehranchi A, Fekrazad R, Zafar M, Eslami B, Kalhori KA, Gutknecht N. Evaluation of the effects of $\mathrm{CO} 2$ laser on debonding of orthodontics porcelain brackets vs. the conventional method. Lasers Med Sci. 2011;26(5):563-567. doi:10.1007/s10103-010-0820-y.

11. Saito A, Namura Y, Isokawa K, Shimizu N. CO2 laser debonding of a ceramic bracket bonded with orthodontic adhesive containing thermal expansion microcapsules. $\mathrm{La}$ sers Med Sci. 2015;30(2):869-874. doi:10.1007/s10103-0131482-3.

12. Hayakawa K. Nd: YAG laser for debonding ceramic orthodontic brackets. Am J Orthod Dentofacial Orthop. 2005;128(5):638-647. doi:10.1016/j.ajodo.2005.03.018.

13. Feldon PJ, Murray PE, Burch JG, Meister M, Freedman MA. Diode laser debonding of ceramic brackets. Am J Orthod Dentofacial Orthop. 2010;138(4):458-462. doi:10.1016/j.ajodo.2008.11.028.

14. Oztoprak MO, Nalbantgil D, Erdem AS, Tozlu M, Arun T. Debonding of ceramic brackets by a new scanning laser method. Am J Orthod Dentofacial Orthop. 2010;138(2):195200. doi:10.1016/j.ajodo.2009.06.024.

15. Nalbantgil D, Oztoprak MO, Tozlu M, Arun T. Effects of different application durations of ER: YAG laser on intrapulpal temperature change during debonding. Lasers Med Sci. 2011;26(6):735-740. doi:10.1007/s10103-0100796-7.

16. Tozlu M, Oztoprak MO, Arun T. Comparison of shear bond strengths of ceramic brackets after different time lags between lasing and debonding. Lasers Med Sci. 2012;27(6):1151-1155. doi:10.1007/s10103-011-1018-7.

17. Dostalová T, Jelinková H, Šulc J, et al. Bond strengths evaluation of laser ceramic bracket debonding. Laser Phys. 2012;22(9):1395-1400. doi:10.1134/s1054660x12090046.

18. Almohaimeed M, El Halim SA. Diode Laser De-Bonding of Pre-Coated Ceramic Brackets. Journal of American Science. 2013;9(5s):177-181.

19. Nalbantgil D, Tozlu M, Oztoprak MO. Pulpal Thermal Changes following Er-YAG Laser Debonding of Ceramic Brackets. ScientificWorldJournal. 2014;2014:912429. doi:10.1155/2014/912429

20. Zach L, Cohen G. Pulp response to externally applied heat. Oral Surgery, Oral Medicine, Oral Pathology. 1965;19(4):515-530. doi:10.1016/0030-4220(65)90015-0.

21. Ivanov PI. Investigation of diode laser debonding of ceramic orthodontic brackets. Nova Southeastern University; 2012.

22. Mundethu AR, Gutknecht N, Franzen R. Rapid debonding of polycrystalline ceramic orthodontic brackets with an Er: YAG laser: an in vitro study. Lasers Med Sci. 2014;29(5):1551-1556. doi:10.1007/s10103-013-1274-9.

23. Wigdor H, Abt E, Ashrafi S, Walsh JT. The effect of lasers on dental hard tissues. J Am Dent Assoc. 1993;124(2):6570. doi:10.14219/jada.archive.1993.0041.

24. Hibst R, Keller U. Experimental studies of the application of the Er: YAG laser on dental hard substances: I. Measurement of the ablation rate. Lasers Surg Med. 1989;9(4):338344. doi:10.1002/lsm.1900090405.

25. Kim YJ, Lim SH, Yoon YJ, Park JC, Kim KW. Histologic changes of pulpal tissue after laser-aided ceramic bracket debonding. Korean J Orthod. 2004;34(4):343-349.

26. Liu X, Wang L, Wang M, Liu L, Wang Q, Zhai J. Histomorphological effects of Nd: YAG laser for debonding ceramic brackets on rabbit pulp (Article in Chinese). Hua Xi Kou Qiang Yi Xue Za Zhi. 2009;27(4):413-416. 